\title{
Examining Prehistoric Migration Patterns in the Palauan Archipelago: A Computer Simulated Analysis of Drift Voyaging
}

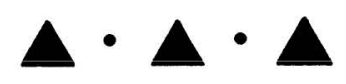

RICHARD CALLAGHAN AND SCOTT M. FITZPATRICK

\section{INTRODUCTION}

Archaeologists WORKING IN THE PACIFIC have long been concerned with how islands in Remote Oceania were colonized prehistorically. To determine patterns of oceanic human dispersal to these islands, researchers have typically relied upon the distribution of stylistically or geochemically unique artifacts (e.g., Descantes et al. 2001; Dickinson and Shutler 2000; Irwin 1978; Pavlish et al. 1986; Weisler 1990, 1998; White 1996; see also Rolett 2002; Rolett et al. 2002), while linguistics and genetic studies have also played an important role in establishing where settlers may have originated (e.g., Bellwood 1997; Blust 2000; Lum 1998; Lum and Cann 2000; Reid 1998; Starosta 1995).

One useful means for investigating voyaging and prehistoric colonization patterns is the recording of traditional seafaring techniques and the experimental construction and use of watercraft based on ancient technologies (see Bechol 1972; Doran 1978; Finney 1988; Lewis 1978; Ling 1970; also Bednarik 1998; Irwin 1998). To complement these studies, computer simulations of seafaring have provided additional data about how peoples may have traveled over time through the Pacific (Avis et al. 2007; Irwin 1992; Levison et al. 1973). However, these and other simulations are not explicitly interested in, nor can they hope to provide great insight, into the timing of human arrival, which must be ascertained instead through careful consideration of radiocarbon chronologies from stratified archaeological and paleoenvironmental deposits. Nonetheless, these experiments can help to refine theories on prehistoric migration routes and direct future research objectives to areas that may be understudied.

Archaeologists have postulated that human populations in the Palauan archipelago (see Fig. 1), may have migrated from Taiwan, Indonesia, New Guinea, or the Philippines based on archaeological, historic, linguistic, and genetic studies (see Bellwood 1997; Irwin 1992; Reid 1998; Semper 1982 [1873]:17-18). To

Richard Callaghan is associate Professor, Department of Archaeology, University of Calgary, Alberta, Canada; Scott M. Fitzpatrick is assistant Professor, Department of Sociology and Anthropology, North Carolina State University, Raleigh. 


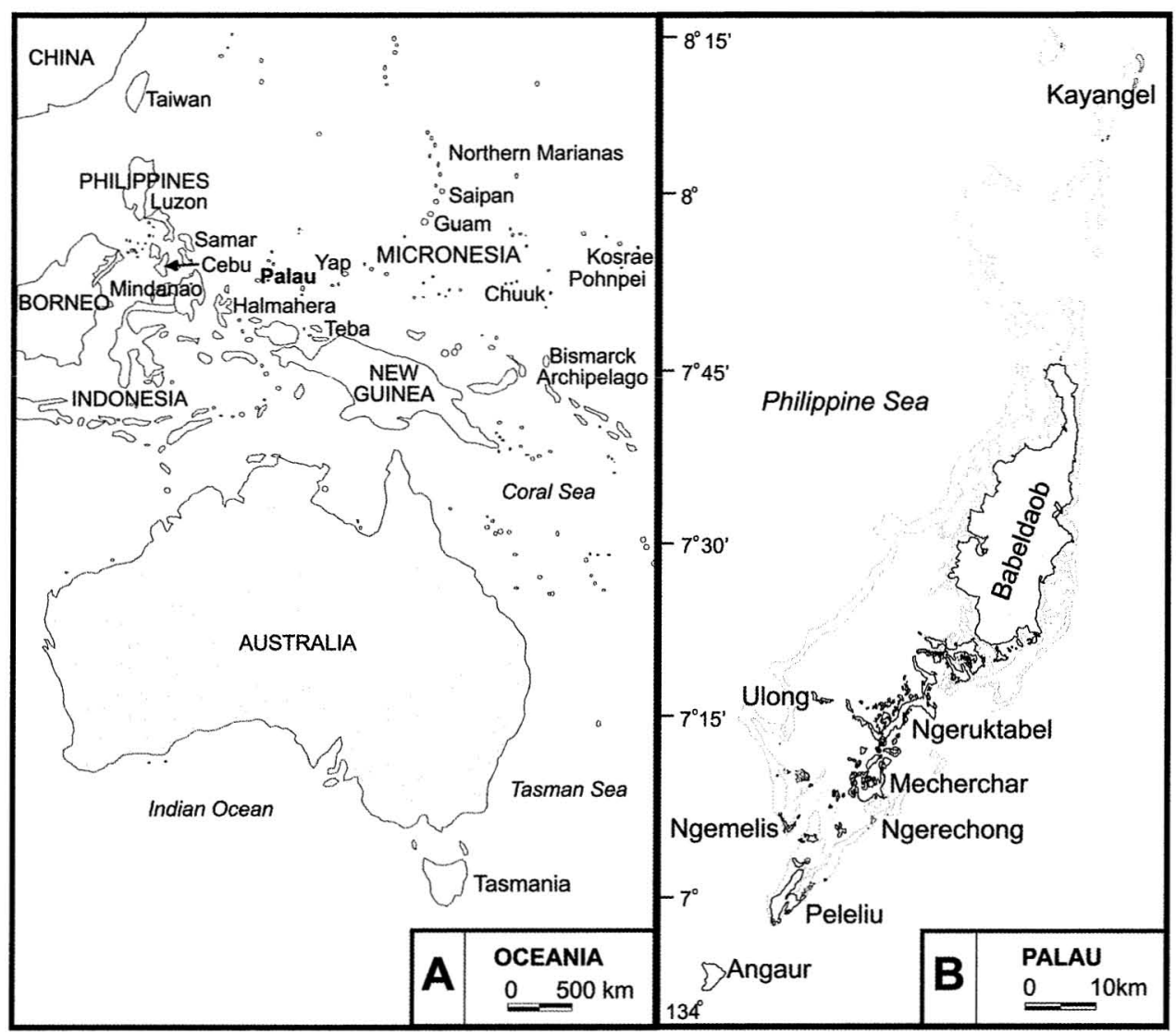

Fig. 1. Maps (left to right) of the western Pacific (A) and the main Palauan archipelago (B).

further examine possible routes of migration to western Micronesian islands, we investigated computer simulated drift voyages to the Palauan archipelago. These simulations take advantage of detailed oceanographic, anemological, and climatological data to determine how watercraft will move or react to ocean conditions during a given time of the year. This type of approach to studying ancient seafaring has been increasingly used worldwide to investigate colonization, migration, and culture contact in the Pacific Islands (Avis et al. 2007; Irwin 1992; Levison et al. 1973), the Caribbean (Callaghan 2001, 2003a), between Ecuador and Mexico (Callaghan 2003b), Costa Rica and Colombia (Callaghan and Bray 2007), from Japan to North America (Callaghan 2003c), and other regions (Montenegro et al. 2006). The results of these simulations can then be coupled with other data to develop more robust hypotheses regarding the human colonization of islands worldwide.

There are a number of voyaging strategies that can be investigated using computer simulations. The two basic divisions are between purposeful or intentional voyages and drift voyages. In this analysis we have chosen to investigate drift voyages. For questions of initial discovery, using a strategy of drift voyages rather 
than purposeful voyages is preferable because it is best to make the fewest assumptions possible in the analysis.

In all of the simulations it was assumed that the crew was lost at sea. Dening (1963:138-153) notes that the limited empirical evidence of known drift voyages in Polynesia suggests a common pattern of behavior in which sailors conclude they are lost early in the voyage and respond by allowing the vessel to drift before the wind with no further attempt to navigate in a particular direction. This strategy allows close to the maximum distance to be covered in a given time when there is no clear indication of relative location.

The Palauan archipelago serves as an interesting case study for conducting computer simulated drift voyages because regional currents and winds are known to have high velocity and volatility which also allowed it to remain virtually isolated from direct European contact until 1783 (Callaghan and Fitzpatrick 2007; Hezel 1972, 1983). For the simulations we focused on testing hypothetical routes from Taiwan, the Philippines (Samar and Mindanao), New Guinea, the Bismarcks, Halmahera, and Guam, all of which have been mentioned in the literature as possible origin points for early Palauans, or in the case of the latter two, had some historical connections with Palau. Historical accounts also testify to the frequency of drift voyages from the Carolines to the Philippines (Hezel 1972, 1983). In 1664, Jesuit missionaries recorded some 30 Carolinian canoes that had accidentally drifted to the Philippines with no less than nine different landings between 1664 and 1669 (Hezel 1972:28). In December 1696, Father Paul Klein, after meeting 30 Carolinians on Samar who had blown off course while sailing from Lamotrek to Fais (Hezel 1972:27), described the events in a letter to the Jesuit General in Rome that spurred a keen interest in conducting exploratory voyages into the Western Carolines.

We first discuss briefly what is presently known about the prehistoric colonization of Palau. Next we describe the local geographic, oceanographic, and anemological conditions which serve to contextualize how these factors may have affected the passage of watercraft. Based on these and other historic data, we then report on the simulations we conducted of drift voyaging to Palau. Results suggest that the southern Philippines would have been the most likely origin for early Palauan settlers, supporting the most widely accepted hypothesis of colonization.

\section{PREHISTORIC COLONIZATION OF WESTERN MICRONESIA}

Using linguistical evidence, Tsang (1992) and Starosta (1995) proposed that the Marianas (e.g., Guam, Saipan, Rota, Tinian) were colonized by peoples from Taiwan. Others such as Reid (1998) have argued that Chamaru (Chamorro) speakers have more immediate links to the Philippines. Recent genetic evidence indicates that the Marianas and Yap were probably settled independently from Island Southeast Asia and that gene flow may have also occurred from centraleastern Micronesia (Lum and Cann 2000:165). Palau appears to have genetic contributions from Southeast Asia, Central-Eastern Micronesia, and New Guinea (Lum and Cann 2000:166).

Based on archaeological investigations, the Marianas appear to have been settled by as early as 3500 в.P. (Butler 1994; Kurashina and Clayshulte 1983; Kur- 
ashina et al. 1984), Yap by at least 2000 в.P. (Gifford and Gifford 1959:159; Intoh 1997; Takayama 1982:91), and Palau sometime in the period 3000-3300 в.P. (Clark 2004, 2005; Fitzpatrick 2002, 2003; Liston 2005). Douglas Osborne (1979) first proposed that the islands were settled in a "stepping-stone" fashion northward beginning around 4500 в.P. based on $\mathrm{C}^{14}$ ages from pottery sherds, an assertion later disputed by Masse (1990) who compiled an additional suite of acceptable radiocarbon dates, none of which was earlier than 2000 B.P. Recent paleoenvironmental studies on all of these island groups (Athens and Ward 2002, 2004; Dodson and Intoh 1999), as well as paleoshoreline evidence in Palau (Dickinson and Athens 2007), however, suggests that colonization may have occurred even earlier around 4000-4500 B.P. Some researchers dispute this proxy evidence without confirmation of associated cultural remains which, although 1000-1500 years earlier than the generally accepted dates from stratified archaeological deposits, seems to be a widespread phenomenon in the region (for discussion of these issues see Athens and Ward 2002, 2004; Welch 1998; Wickler 2001, 2004).

Despite the complex settlement pattern that has emerged, involving genetically distinct populations from various regions over time, it now appears likely that prehistoric settlement of the region was relatively contemporaneous, whether one accepts the short (archaeological) or long (paleoenvironmental) sequence of occupation. Unfortunately, a general paucity of archaeological research has prevented the establishment of clearer linkages between possible staging areas in Island Southeast Asia or Melanesia and western Micronesian islands.

\section{ENVIRONMENTAL BACKGROUND}

Palau consists of several hundred islands - the largest of these is Babeldaob which is $330 \mathrm{~km}^{2}$ and the second largest island in Micronesia next to Guam. The main archipelago is roughly $800 \mathrm{~km}$ equidistant from the Philippines to the west and Irian Jaya to the south. Palau, situated at $7^{\circ} 30^{\prime}$ north of the equator and surrounded by a complex barrier reef system, is over $160 \mathrm{~km}$ long, $25 \mathrm{~km}$ across at its widest point, and oriented in a northeast-southwest direction.

The main climatic feature in western Micronesia is the equatorial trough of low pressure that induces an airflow known as the Northeast Trades (see Siedler and Church 1951; see also Hazell and Fitzpatrick 2006). These occur throughout the winter and spring from October to May (Morris 1988) and are fairly consistent winds with a mean speed of around 10 knots $(18 \mathrm{kmh})$. With decreasing northeast trade winds in the month of April, the east winds are more frequent and become dominant in the region. On average, the mean wind velocity decreases from $10.5 \mathrm{~km}$ per hour in January to $5.8 \mathrm{~km}$ per hour in June, primarily due to the development of the Australian anticyclone that shifts the prevailing winds (Corwin et al. 1956). From July through October, winds are comparatively light with the mean monthly velocity ranging between 0.5 and $1.5 \mathrm{~km}$ per hour.

The Northeast Trades offer a comparatively consistent velocity and direction. This has two advantages for sailing - a constant wind direction that aids navigation on the open sea and a constant southeast or northeast ocean swell (depending on the month). Outside of the Northeast Trades, the highest number of days for winds originating from any given direction occurs in September. These 4-7 
knot $(7.2-12.6 \mathrm{kmh})$ winds come from the southwest for about seven days (Morris 1988; United States Navy 1995). Calms (or low wind velocity) are reported for a similar number of days.

Palau is located at the junction of three major ocean currents-the North Equatorial Current (NEC), Equatorial Counter Current (ECC), and the South Equatorial Current (SEC). The formation of these can produce considerable seasonal current pattern changes in the region (Gatty 1944; Irwin 1992; Jenkins 1973; Morris 1988; Rapaport 1999; United States Navy 1995). Between Yap and Palau, for example, ocean currents are fairly consistent for most of the year, with only minor local variations in and around the various islands and reef systems (Heyen 1972; see also Hazell and Fitzpatrick 2006). The currents flow east to west at around 0.75 to $1.25 \mathrm{knots}(2.5 \mathrm{~km} / \mathrm{h})$, except from August to October when there is a variable, weaker northeast current (although a rate of 3 knots has been reported) (Morris 1988). During September, surface currents can have a northwest to southwest set. The variable winds and surface currents also make this and other months with similar conditions difficult periods for sailing. Changes in the basic features of the waves such as shape, frequency, and size are known to alert navigators to the proximity of land (Gatty 1944; Golson 1972; Heyen 1972). Based on these data collected in greater detail as part of the U.S. Navy's (1995) Marine Climatic Atlas of the World, we can simulate voyages under a host of varying conditions to hypothesize from where Palauan colonists may have originated.

\section{COMPUTER SIMULATIONS OF VOYAGING}

The problem of predicting from where prehistoric peoples were most likely to have discovered Palau is addressed here using computer simulations based on the known patterns of winds and currents throughout the year. When running simulated drift voyages, four main variables are considered: (1) current patterns; (2) wind patterns; (3) vessel type; and (4) propulsion. The structure of the simulation is the actual mechanics of the program; for example, how data are selected and success as a percentage of all voyages calculated. Parameters include such factors as the starting position of the vessel, drift or directed voyage, duration at sea, and what constitutes a successful voyage.

Currents will affect any objects caught in them in a $1: 1$ ratio. That is, the object will have the same speed and set as the current unless other forces are operating. Any object floating with an appreciable part above the water will be more affected by wind than by currents unless the current is an exceptionally strong one. The effect of wind on objects floating high in the water was used by traditional navigators in Kiribati to determine the direction of land when recent winds differed from the flow of the current (Lewis 1972:212). The source of wind and current data is the CD-ROM version of the U.S. Navy's Marine Climatic Atlas of the World (Version 1.1, 1995).

The type of vessel and how it is propelled make up the final variables of the problem, as the shape of an object both above and below the waterline will dictate wind effects. However, in this problem, we do not know what types of vessels were used prehistorically, but some form of sailing canoe is likely (see Doran 1981). Speeds at which the vessels used in this simulation can travel under various wind conditions are taken from figures provided by Levison et al. (1973).

The program itself is based on the U.S. Navy's Marine Climatic Atlas (1995) and 
it has been expanded to include all of the world's seas and oceans with the exception of Arctic waters. The data are organized in a resolution of one degree Marsden squares (one degree of longitude by one degree of latitude). In particular, this resolution allows the effects of smaller and more variable currents to be accurately reflected in the outcomes. The program randomly selects wind and current data that are frequency-weighted according to the compiled observations of the Marine Climatic Atlas. These forces are then allowed to operate on vessels for a twentyfour-hour period before a new selection is made (see Levison et al. 1973 for a justification of the period length).

The actual distance and direction traveled are based on the wind and current data combined with the speeds from Levison et al. (1973:19) and parameters selected by the program operator. Examples of parameters here include the use of sails, sea anchors to keep a vessel oriented into the wind during storms, or drogues to slow the vessel and prevent following seas from swamping the vessel. It is also possible to include here changes of bearing when under sail. This last feature is important when assessing the level of navigational skill required to reach a selected target during directed voyages. The program automatically shifts to the database for the following month after the month originally selected has expired. This feature better reflects the reality of changing wind and current conditions over long voyages. The result of the simulations is expressed as the percentage of successes for a particular vessel type from selected points.

Parameters of the simulation are choices made by the program operator in order to set up the simulation to answer a particular question. This includes the following information: (1) point of origin and destination; (2) crew strategy; (3) performance characteristics; (4) duration of voyages; (5) time of year; and (6) number of simulations. Seven points of origin were used with Palau as the destination. These were southern Taiwan; east of Samar (central Philippines); southeast of Mindanao (southern Philippines); north of Teba on New Guinea; north of Halmahera; north of the Bismarck Archipelago.

The second parameter is the strategy used by the crew. In all of the simulations it was assumed that the crew was lost at sea. As noted above, Dening (1963:138153) states that the limited empirical evidence of known drift voyages in Polynesia suggests a common pattern of behavior in which sailors conclude they are lost early in the voyage and respond by allowing the vessel to drift before the wind with no further attempt to navigate in a particular direction. This strategy allows close to the maximum distance to be covered in a given time when there is no clear indication of relative location. In this case, the performance characteristics are simply the speed for small vessels sailing before the wind (provided by Levison et al. 1973:19).

For this type of question, using a strategy of drift voyages rather than directed voyages is preferable. Looking at initial discovery, it is best to make the fewest assumptions as possible in the analysis. A drift strategy limits decisions on the part of the operator. In virtually all cases, if it is easy to discover point B from point A in a drift voyage, it will easier to navigate to point $B$ once its location is known. Directed voyages are better used when evaluating the navigation skill needed when traveling between two points after initial discovery.

The duration of the drift voyages was set to 75 days after which it was assumed that the crew perished. Seventy-five days would by no means be the longest drift voyage in an open boat due to shipwreck or other misfortunes documented in the 
Table i. Success Rates for Drift Voyages to Palau and Durations in Days

\begin{tabular}{|c|c|c|c|c|c|c|c|c|c|c|c|c|}
\hline & JANUARY & FEBRUARY & MARCH & APRIL & MAY & JUNE & JULY & AUGUST & SEPTEMBER & OCTOBER & NOVEMBER & DECEMBER \\
\hline Taiwan & $0 \%$ & $0 \%$ & $0 \%$ & $0 \%$ & $0 \%$ & $0 \%$ & $0 \%$ & $0 \%$ & $0 \%$ & $0 \%$ & $0 \%$ & $0 \%$ \\
\hline Samar & $0 \%$ & $0 \%$ & $0 \%$ & $0 \%$ & $0 \%$ & $0 \%$ & $0 \%$ & $0 \%$ & $0 \%$ & $0 \%$ & $0 \%$ & $0 \%$ \\
\hline Mindanao & $0 \%$ & $0 \%$ & $0 \%$ & $0 \%$ & $0 \%$ & $1 \%(42)$ & $2 \%(11,19)$ & $2 \%(11,13)$ & $11 \%(10-30)$ & $10 \%(13-56)$ & $1 \%(22)$ & $0 \%$ \\
\hline Halmahera & $0 \%$ & $0 \%$ & $0 \%$ & $0 \%$ & $0 \%$ & $10 \%(15-32)$ & $17 \%(8-17)$ & $18 \%(9-28)$ & $35 \%(9-34)$ & $5 \%(39-75)$ & $0 \%$ & $0 \%$ \\
\hline Teba NG & $0 \%$ & $0 \%$ & $0 \%$ & $0 \%$ & $0 \%$ & $0 \%$ & $1 \%(15)$ & $0 \%$ & $0 \%$ & $0 \%$ & $0 \%$ & $0 \%$ \\
\hline $\begin{array}{l}\text { Bismarck } \\
\text { Archipelago }\end{array}$ & $0 \%$ & $0 \%$ & $0 \%$ & $0 \%$ & $0 \%$ & $0 \%$ & $0 \%$ & $0 \%$ & $0 \%$ & $0 \%$ & $0 \%$ & $0 \%$ \\
\hline
\end{tabular}


Pacific (Howay 1944; Levison et al. 1973:20-21). The maximum recorded drift seems to be on the order of seven to eight months and several of these have been documented in the last few decades. A number of these recorded voyages covered distances of around $5500 \mathrm{~km}$ over a period of six to ten weeks, and even more traveled slightly shorter distances. For the purposes of this study, 100 drift voyages were simulated for all 12 months of the year from each of the points of origin.

\section{RESULTS OF SIMULATIONS}

Table 1 gives the success rates for drift voyages to Palau and the durations in days. No voyages were successful from Taiwan, Samar, or the Bismarck Archipelago at any time of the year. From the area of Teba on New Guinea, only one voyage in July conditions was successful, lasting for 15 days. Figure 2 shows the drift voyages for July. From Mindanao, drift voyages were successful under June to November conditions (Fig. 3). Success rates are from 1 to 11 percent with durations of 10 to 56 days. The average number of days successful voyages took was 23. Voyages starting in September had the highest rate of success (11 percent). Voyages originating off Halmahera had by far the greatest chance of success from June to October. Rates of success were from 5 to 35 percent. Voyages beginning under September conditions (Fig. 4) had the highest success rate. Durations ranged from 8 to 75 days with an average of 26 days. It should be noted that under October conditions, the average durations were 62 days which somewhat biases the overall average. Simulations are also shown from the Bismarck Archipelago (Fig. 5) to show drift voyages from a point that were completely unsuccessful in reaching Palau.

\section{DISCUSSION AND CONCLUSIONS}

The computer simulations we conducted suggest that voyagers drifting from off western New Guinea would have had only a minimal chance of reaching the Palauan archipelago while Taiwan, the Bismarcks, and Samar were unlikely origins. Peoples sailing before the wind from Mindanao and Halmahera to Palau would have had the most success of landfall. The high rate of success at finding Palau from Halmahera (35 percent) is explained by the higher than normal winds coming from the southwest during the month of September (Morris 1988). In addition, sailors departing from the southern Philippines, even if they were unable to reach Palau, would have had a good chance of returning home. This also helps to explain the significant number of Carolinian canoes that ended up drifting there (Hezel 1972:27-28).

These computer-simulated drift voyages support an initial discovery and migration from the southern end of the Philippines based on the high rate of success in finding Palau. If Palau was in fact first settled by Austronesian (western MalayoPolynesian) speaking groups from the Philippines (see Bellwood 1997:105-107; Craib 1999; Wickler 2001), it appears more likely that they would have come from the most southerly of the islands. It should be noted, however, that we are not suggesting that peoples could not have voyaged to Palau from other locations either purposefully or accidentally. Our simulations do suggest chance occurrences of drifting from New Guinea to Palau, but this was very low (1 percent). Based on mtDNA lineage analyses of Palauan samples, Lum and Cann 
$\longleftarrow z]_{\underline{\underline{0}}}^{\underline{\underline{0}}}$
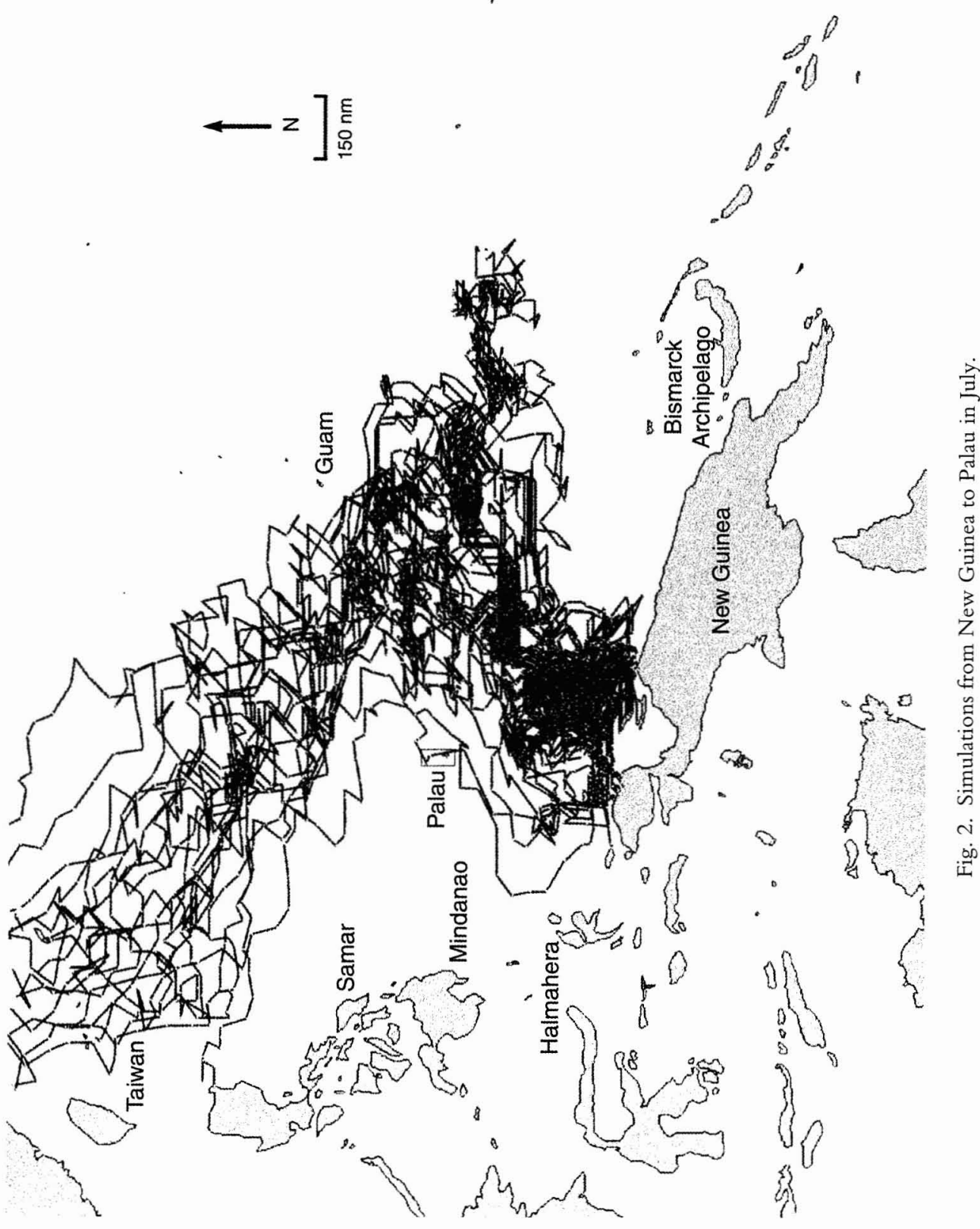


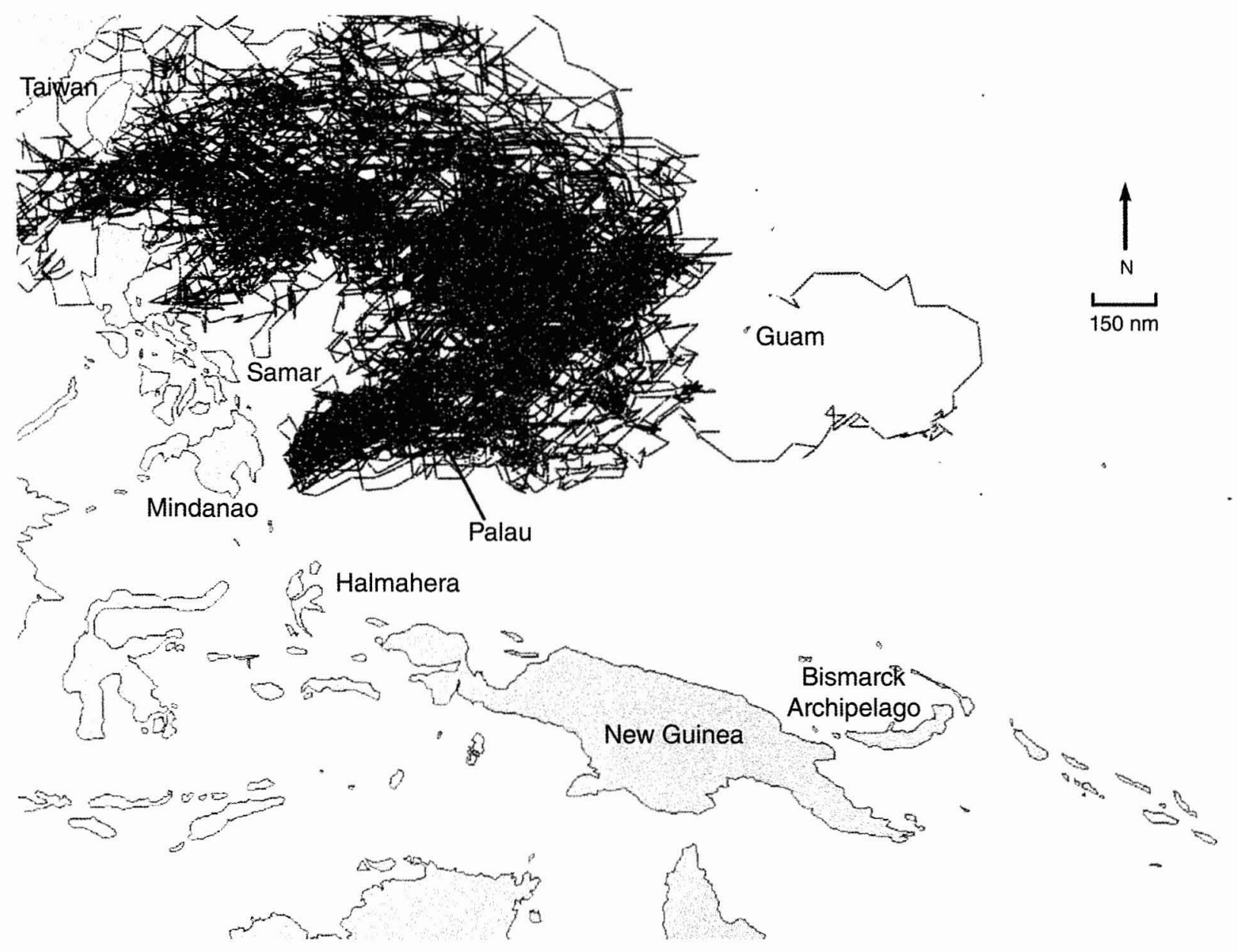

Fig. 3. Simulations from Mindanao to Palau in September. 


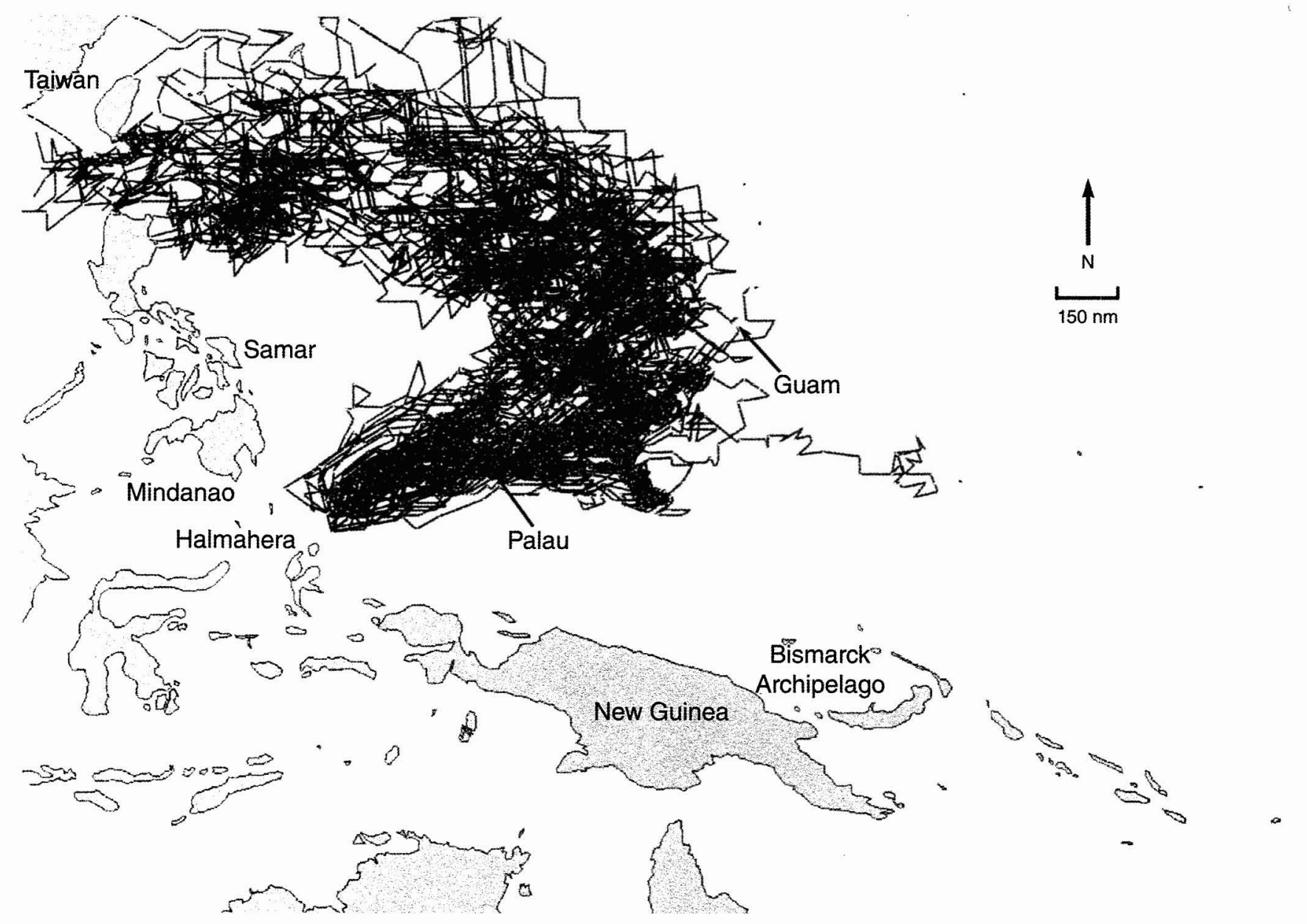

Fig. 4. Simulations from Halmahera to Palau in September. 


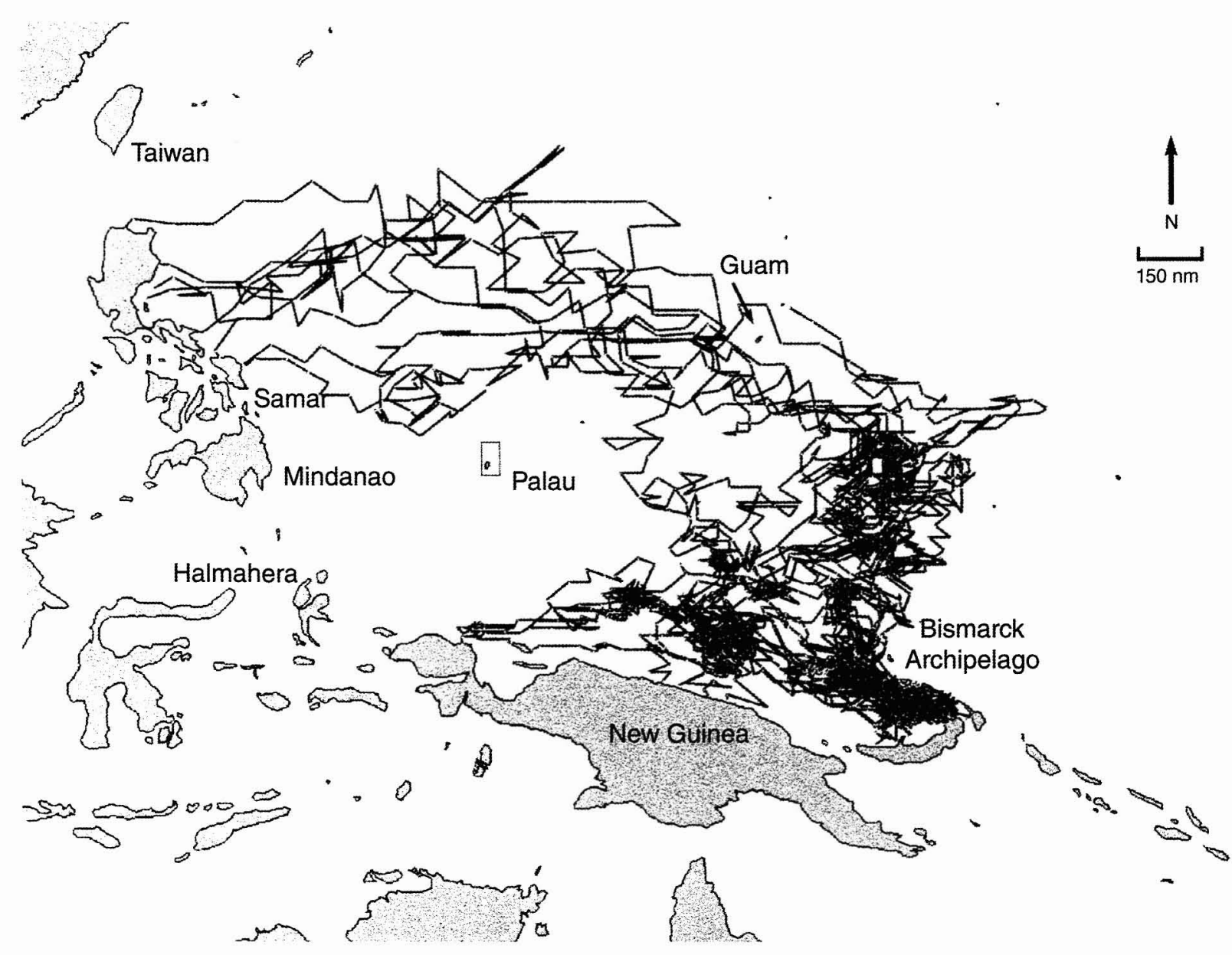

Fig. 5. Simulations from the Bismarck Archipelago to Palau in October. 
(2000: 166) noted that migration to Palau occurred "from both Island Southeast Asia and Central-Eastern Micronesia," but that the diversity of sequences may also be a result of "an early migration by a small number of individuals from New Guinea." In addition, some similarities found in ceramics (Specht et al. 2006) and rock art (Rainbird 2004:49,146) between Palau and western New Guinea may indicate cross-cultural interaction, but to date, no direct evidence of prehistoric artifact movement between these locations has been reported.

The simulations we conducted give us a better sense of the challenges that prehistoric explorers faced when attempting to venture to Palau. It is true that increasingly sophisticated navigational and sailing techniques would have enabled ancient mariners to overcome many of the oceanographic and anemological conditions found in western Micronesia. However, the high rates of drifting recorded historically, and the difficulties encountered by Europeans when attempting to find Palau, still make these conditions an influential part in structuring the colonization of the archipelago prehistorically and dramatically reduced the chances of Europeans finding these islands (Callaghan and Fitzpatrick 2007; Hezel 1972).

Computer-simulated drift voyages have proven to be a useful exercise for helping to establish the origin of prehistoric settlers to Palau and the paucity of historical contacts made. Future research will be dedicated to continued examination of prehistoric settlement strategies and historic contacts in Micronesia using similar approaches and trying to develop hypotheses as to why other islands throughout the Pacific appear to have been contacted much later than others. It will also be useful to consider drift voyaging as it relates to the introduction of new prestige items such as glass beads in Palau (Ritzenthaler 1954) and rice in the Marianas that post-dates initial colonization (Hunter-Anderson et al. 1995). These and other questions which we are now exploring not only have important implications for understanding settlement strategies and the limitations placed on ancient sea voyagers, but how contact between various groups in Oceania was, in many ways, directly influenced by the dynamic and often unpredictable winds and currents.

\section{ACKNOWLEDGMENTS}

This paper was originally presented at the Indo-Pacific Prehistory Association Congress in Manila, Philippines, 20-26 March 2006. We thank everyone on the staff of the Palau Bureau of Arts and Culture who have been great supporters of archaeological and archival research conducted on Palau. Thanks also to Atholl Anderson and Sue O'Connor for helping to organize and moderate the original IPPA session and inviting us to contribute the paper to this special issue of the journal.

\section{REFERENCES CITED}

Athens, J. S., AND J. WARD

2002 Paleoenvironmental evidence for early human settlement in Palau: The Ngerchau core, in Pacific 2000 Conference Proceedings: 165-178, ed. G. Lee. Los Osos: Easter Island Foundation.

2004 Holocene vegetation, savanna origins, and human settlement of Guam. Records of the Australian Muscum, Supplement 29:15-30.

Avis, C., A. Montenegro, and A. Weaver

In Press The discovery of western Oceania: A new perspective. Journal of Island and Coastal Archaeology. 
BeCHOL, C.

1972 Sailing characteristics of oceanic canoes, in Polynesian Navigation: 98-101, ed. J. Golson. Wellington: A. H. and A. W. Reed.

BEDNARIK, R. G.

1998 Mariners of the Pleistocene. International Journal of Nautical Archaeology 25:7-15.

Bellwood, P.

1997 Prehistory of the Indo-Malaysian Archipelago, 2nd ed. Honolulu: University of Hawai'i Press.

BLUST, R.

2000 Chamorro historical phonology. Oceanic Linguistics 39:83-122.

Butler, B. M.

1994 Early prehistoric settlement in the Marianas Islands: New evidence from Saipan. Man and Culture in Oceania 10:15-38.

Callaghan, R. T.

2001 Ceramic age seafaring and interaction potential in the Antilles: A computer simulation. Current Anthropology 42(2): 11-22.

$2003 a$ Comments on the mainland origins of the Preceramic cultures of the Greater Antilles. Latin American Antiquity 14(3):323-338.

$2003 b$ Prehistoric trade between Ecuador and west Mexico: A computer simulation of coastal voyages. Antiquity 77(298): 796-804.

2003 c The use of simulation models to estimate frequency and location of Japanese Edo period wrecks along the Canadian Pacific Coast. Canadian Journal of Archaeology 27(1):62-82.

Callaghan, R. T., And W. Bray

2007 Simulating prehistoric sea contacts between Costa Rica and Colombia. Journal of Island and Coastal Archaeology $2: 4-23$.

Callaghan, R. T., and S. M. Fitzpatrick

2007 On the relative isolation of a Micronesian archipelago during the Historic Period: The Palau case study. International Journal of Nautical Archaeology 36(2):353-364.

Clark, G.

2004 Radiocarbon dates from the Ulong site in Palau and implications for western Micronesian prehistory. Archaeology in Oceania 39:26-33.

2005 A 3000-year culture sequence from Palau, Western Micronesia. Asian Perspectives $44(2): 350-380$.

Corwin, C. G., C. L. Rogers, and P. O. Elmquist

1956 Military geology of Palau Islands. Honolulu: Intelligence Division, Office of the Engineer, Headquarters United States Army Far East.

CRAIB, J

1999 Colonisation of the Mariana Islands: New evidence and implications for human movements in the western Pacific, in Le pacifique de 5000 à 2000 avant le présent. Suppléments à l'histoire d'une colonization. The Pacific from 5000 to 2000 B.P. Colonisation and Transformation: 477-485, ed. J. C. Galipaud and I. Lilley. Actes du colloque Vanuatu, 31 Juillet6 Aout 1996. Paris: Éditions de l'ORSTROM. Collection Colloques et seminaries.

Dening, G. M.

1963 The geographical knowledge of the Polynesians and the nature of inter-island contact, in Polynesian Navigation: 138-153, ed. J. Golson. Polynesian Society Memoir No. 34, Wellington.

Descantes, C., H. Neff, M. D. Glascock, and W. R. Dickinson

2001 Chemical characterization of Micronesian ceramics through Instrumental Neutron Activation Analysis: A preliminary provenance study. Journal of Archaeological Science 28: 1185-1190.

Dickinson, W. R., AND J. S. Athens

2007 Holocene paleoshoreline and paleoenvironmental history of Palau: Implications for human settlement. Journal of Island and Coastal Archaeology 2(2): 175-196.

Dickinson, W. R., and R. Shuther

2000 Implications of petrographic temper analysis for Oceanian prehistory. Journal of World Prehistory $14: 203-266$. 
Dodson, J. R., AND M. InTOH

1999 Prehistory and palaeoecology of Yap, Federated States of Micronesia. Quaternary International 59:17-26.

DORAN, E.

1978 Seaworthiness of sailing rafts. Anthropological Journal of Canada 16:17-22.

1981 Wangka, Austronesian canoe origins. College Station: Texas A\&M University Press.

FINNEY, B.

1988 Voyaging against the direction of the trades. American Anthropologist 90:401-405.

FitzPATRICK, S. M.

2002 AMS dating of human bone from Palau: New evidence for a pre-2000 BP settlement. Radiocarbon $44: 217-221$.

2003 Early human burials in the western Pacific: Evidence for a c. 3000 year old occupation on Palau. Antiquity 77(298):719-731.

GAтTY, H.

1944 The raft book. New York: George Grady Press.

GiFFORD, E. W., AND D. S. GiFFord

1959 Archaeological excavations in Yap. Anthropological Records 18(2):149-224. Berkeley: University of California Press.

Golson, J., ED.

1972 Polynesian Navigation. Wellington: A. H. and A. W. Reed.

Hazell, L., AND S. M. Fitzpatrick

2006 The maritime transport of megaliths in Micronesia. Archaeology in Oceania 41:12-24.

HEYen, C.G.H.

1972 Primitive navigation in the Pacific, in Polynesian navigation: 64-79, ed. Golson. Wellington: A. H. and A. W. Reed.

Hezel, F. X.

1972 Early European contact with the Western Carolines. Journal of Pacific History $7: 26-44$.

1983 The first taint of civilization: A history of the Caroline and Marshall Islands in pre-colonial days, 1521-1885. Pacific Islands Monograph Series 1. Honolulu: University of Hawai'i Press.

Howay, Frederic W.

1944 Some lengthy open-boat voyages in the Pacific Ocean. American Neptune 4:53-57.

Hunter-Anderson, R. L., G. B. Thompson, and D. R. Moore

1995 Rice as a prehistoric valuable in the Mariana Islands, Micronesia. Asian Perspectives $34: 69-90$.

INTOH, $M$.

1997 Human dispersals into Micronesia. Anthropological Science 105:15-28.

IRWIN, G.

1978 Pots and entrepôts: A study of settlement, trade, and the development of economic specialization in Papuan prehistory. World Archaeology 9:299-319.

1992 The prehistoric exploration and colonization of the Pacific. Cambridge: Cambridge University Press.

1998 The colonisation of the Pacific plate: Chronological, navigational, and social issues. Journal of the Polynesian Society 107:111-143.

JENKINS, H.L.C.

1973 Ocean passages for the world. Taunton, Somerset: Hydrographer of the Navy.

Kurashina, H., and R. N. Clayshulte

1983 Site formation processes and cultural sequence at Tarague, Guam. Bulletin of the IndoPacific Prehistory Association $4: 114-122$.

Kurashina, H., D. Moore, O. Kataoka, R. Clayshulte, and E. Ray

1984 Prehistoric and protohistoric cultural occurrences at Tarague, Guam. Asian Perspectives 24:57-68.

LeVison, M., R. G. WARD, AND J. W. WebB

1973 The settlement of Polynesia, a computer simulation. Canberra: Australian National University Press. 
LEWIS, D.

1972 We, the navigators. Honolulu: University of Hawai'i Press.

1978 The voyaging stars. Sydney: Williams Collins Publishing Pty. Ltd.

LING, S.-S.

1970 A study of the raft, outrigger, double and deck canoes of Ancient China, the Pacific and the Indian Ocean. Institute of Ethnology, Academia Sinica. Republic of China, Nankang, Taipei, Taiwan.

Liston, J.

2005 An assessment of radiocarbon dates from Palau, western Micronesia. Radiocarbon 47:295354.

LuM, J. K.

1998 Central and eastern Micronesia: Genetics, the overnight voyage, and linguistic divergence. Man and Culture in Oceania 14:69-80.

LUM, J. K., AND R. L. CANN

2000 MtDNA lineage analysis: Origins and migrations of Micronesians and Polynesians. American Journal of Physical Anthropology 113:151-168.

Masse, W. B.

1990 Radiocarbon dating, sea level change and the peopling of Palau. Micronesica Supplement $2: 213-30$

Montenegro, Á., R. Hetherington, M. Eby, and A. J. Weaver

2006 Modelling pre-historic transoceanic crossings into the Americas. Quaternary Science Reviews $25: 1323-1338$.

Morris, R. O., Rear Admiral, Hydrographer of the Navy

1988 Pacific islands pilot, one. Taunton, Somerset: Hydrographic Dept., Ministry of Defense.

National Imagery and Mapping Agency

1998 NVPub. 107 Atlas of Pilot Charts South Pacific Ocean. National Imagery and Mapping Agency.

OSBORNE, D.

1979 Archaeological test excavations in the Palau Islands, 1968-69. Micronesica Supplement 1.

Pavlish, L. A., R.G.V. Hancock, D. Snyder, and L. Lucking

1986 INAA study of pottery from Palau, Micronesia, in Proceedings of the 24th International Archaeometry Symposium: 381-387, ed. J. Olin and M. J. Blackman. Washington, D.C.:

Smithsonian Institution Press.

RAINBIRD, P.

2004 The archaeology of Micronesia. Cambridge: Cambridge University Press.

RAPAPORT, M.

1999 The Pacific Islands: Environment and society. Honolulu: Bess Press.

REID, L.

1998 Morphosyntactic evidence for the position of Chamorro in the Austronesian language family. Paper presented at the 16th Congress of the Indo-Pacific Prehistory Association, Melaka, Malaysia, 1-7 July 1998.

Ritzenthaler, R. E.

1954 Native money of Palau. Milwaukee: Milwaukee Public Museum Publications in Anthropology No. 1.

ROLETT, B. V.

2002 Voyaging and interaction in ancient East Polynesia. Asian Perspectives 41:182-194.

Rolett, B. V., J. Tianlong, and L. Gongwu

2002 Early seafaring in the Taiwan Strait and the search for Austronesian origins. Journal of East Asian Archaeology $4: 307-319$.

SEMPER, K.

1982 The Palau Islands in the Pacific Ocean. Translation by Mark L. Berg. Micronesian Area Re[1873] search Center, University of Guam, Agana.

Siedler, G., And J. Church

2001 Ocean circulation and climate: Observing and modeling the global ocean. San Diego: Academic [1951] Press. 
Specht, J., I. Lilley, AND W. R. Dickinson

2006 Type X pottery, Morobe Province, Papua New Guinea: Petrography and possible Micronesian relationships. Asian Perspectives $45: 24-47$.

Starosta, S.

1995 A grammatical subgrouping of Formosan languages, in Austronesian Studies Relating to Taiwan: 683-726, ed. P. Li, C. H. Tsang, Y. K. Huang, D. A. Ho, and C. Y. Tseng. Taipei: Academia Sinica.

TAKAYAMA, J.

1982 Archaeological research in Micronesia during the past decade. Bulletin of the Indo-Pacific Prehistory Association 3: 95-114.

TSANG, C-H.

1992 Archaeology of the P'eng-Hu Islands. Institute of History and Philology Special Publication No. 95. Taipei: Academia Sinica.

United States Navy

1995 Marine Climatic Atlas of the World. National Climatic Data Center, Asheville, NC.

WEISLER, M.

1990 Sources and sourcing of volcanic glass in Hawai'i: Implications for exchange studies. Archaeology in Oceania 25:16-23.

1998 Hard evidence for prehistoric interaction in Polynesia. Current Anthropology 39:521-532.

WELCH, D.

1998 Integration of the archaeological and paleoenvironmental evidence of early human settlement in Palau. Bulletin of the Indo-Pacific Prehistory Association 17:80.

White, J. P.

1996 Rocks in the head: Thinking about the distribution of obsidian in Near Oceania, in Oceanic culture history: Essays in honour of Roger Green: 199-209, ed. J. Davidson, G. Irwin, F. Leach, A. Pawley, and D. Brown. New Zealand Journal of Archaeology.

WICKLER, S.

2001 The colonization of western Micronesia and early settlement in Palau, in Pacific 2000 Conference Proceedings: 185-196, ed. G. Lee. Los Osos: Easter Island Foundation.

2004 Modeling the colonization of western Micronesia: A review of recent evidence focusing on Palau, in Micronesia: Visiones desde Europe. 2. ${ }^{\circ}$ coloquio europeo sobre Micronesia: 2342, ed. B. Moral. Madrid: Asociación Española de Estudíos del Pacifico.

\begin{abstract}
A number of recent genetic, linguistic, and archaeological studies have attempted to ascertain the origin of settlers to the Palauan archipelago, but it remains a complex and debated issue. To provide additional insight into colonization strategies and settlement patterns, we conducted computer simulations of drift voyages to the Palauan archipelago based on historically recorded winds and currents. Drift voyages were considered here as drifting before the wind when lost, a strategy documented for Pacific Islanders. The simulations suggest that peoples drifting before the wind from the southern Philippines would have had the most success in landfall. This finding supports the current hypothesis of human colonization to the islands of Palau. KEYwords: Computer simulation, drift voyaging, seafaring, colonization, Palau, Micronesia.
\end{abstract}

